\title{
Antimicrobial effect of essential oils of Laurus nobilis L. and Rosmarinus officinallis L. on shelf-life of minced "Maronesa" beef stored under different packaging conditions ${ }^{\text {is }}$
}

\author{
Joana Vilela ${ }^{\mathrm{a}}$, Dirce Martins ${ }^{\mathrm{a}}$, Filipe Monteiro-Silva ${ }^{\mathrm{b}}$, Gerardo González-Aguilar ${ }^{\mathrm{b}}$, \\ José M.M.M. de Almeida ${ }^{\mathrm{b}, \mathrm{c}}$, Cristina Saraiva ${ }^{\mathrm{a}, *}$ \\ a School of Agrarian and Veterinary Sciences, CECAV, University of Trás-os-Montes e Alto Douro, Apartado 1013, P 2, 5001-801 Vila Real, Portugal \\ b Centre for Applied Photonics, INESC TEC, Faculty of Sciences of University of Porto, 4169-007 Porto, Portugal, Portugal \\ ${ }^{\mathrm{c}}$ Department of Physics, School of Sciences and Technology, University of Trás-os-Montes e Alto Douro, Apartado 1013, 5001-801 Vila Real, Portugal
}

\section{A R T I C L E I N F O}

\section{Article history:}

Received 30 October 2015

Received in revised form 25 March 2016

Accepted 25 April 2016

Available online 30 April 2016

\section{Keywords:}

Essential oils

Spoilage microorganisms

Food safety

Shelf-life

Gas chromatography

\section{A B S T R A C T}

The aim of this study was to evaluate the effect of essential oils (EOs) of plants naturally occurring in northern Portugal on the spoilage of fresh Maronesa beef burgers stored at 2 and $8{ }^{\circ} \mathrm{C}$ under different packaging conditions.

EOs were obtained from dried leaves of laurel (Laurus Nobilis L.) and rosemary (Rosmarinus officinallis L.) by hydro-distillation using a Clevenger-type apparatus. Analysis of volatile composition of essential oils of rosemary and laurel was achieved by Gas Chromatography-Mass Spectrometry (GC-MS) and Gas Chromatography-Thermal Conductivity Detection (GC-TCD) resulting in the detection of $95.8 \%$ and $89.4 \%$ of its compounds, respectively.

Fresh beef (semitendinosus and semimembranosus) of DOP-Maronesa breed (males; $n=4$ ) were obtained from local market and transported to the laboratory. Samples were stored at 2 and $8{ }^{\circ} \mathrm{C}$ in two different conditions: aerobiosis (A) and vacuum (V) and analyzed at 0,1, 2, 3, 5, 7, 10,14, 21 and 28 days for Lactic acid bacteria (LAB), Enterobacteriaceae,Pseudomonas spp., Fungi, Total mesophilic (TM) and psychrotrophic (TP), color ( $\left.\mathrm{L}^{*} \mathrm{a}^{*} \mathrm{~b}^{*}\right)$ and $\mathrm{pH}$.

Laurel was the most effective EO keeping $\mathrm{pH}$ from increasing. Coordinates $\mathrm{L}^{*}$ and $\mathrm{a}^{*}$ were higher on samples containing laurel EO for both A and V packaging. Laurel also showed better effect in reducing microbiologic counts in samples packed in $\mathrm{A}$ at both 2 and $8^{\circ} \mathrm{C}$ and packed in $\mathrm{V}$ at $8{ }^{\circ} \mathrm{C}$. Rosemary was effective in reducing microbial counts on all $\mathrm{V}$ samples stored at $2^{\circ} \mathrm{C}$.

This study allows to conclude that Laurel EO has significant effect in shelf-life, maintaining fresh beef color.

(c) 2016 Elsevier Ltd. All rights reserved.

\section{Introduction}

Meat is a major source of protein of high biological value for humans (Lund, Heinonen, Baron, \& Estévez, 2011), being also a source of other important nutrients. It is an ideal substrate for the development of deteriorative and pathogenic microorganisms, therefore it is important to ensure the safety of its consumption (Kodogiannis, Pachidis, \& Kontogianni, 2014).

\footnotetext{
The manuscript was presented at 'Innovations in Food Packaging, Shelf Life and Food Safety'held on 15-17th September 2015, in Erding, Germany. http://www. foodpackconference.com/.

* Corresponding author.

E-mail address: crisarai@utad.pt (C. Saraiva).
}

Minced meat has a reduced shelf life when compared to whole meat, since the surface area exposed to the external environment is increased (Limbo, Torri, Sinelli, Franzetti, \& Casiraghi, 2010). The best way to improve food safety and shelf life is minimizing contamination and slowing or even inhibiting the growth of deteriorative and pathogenic microorganisms (Sallam \& Samejima, 2004).

Deterioration of fresh meat can be subjective since it depends on the culture, economic capacity, level of education and sensory acuity of consumers. Although deterioration is not always apparent, the following aspects are commonly considered as the main criteria for rejection: discoloration, off-odors and off-flavors and slime appearance (Ellis, Broadhurst, Kell, Rowland, \& Goodacre, 2002). 
There are several factors that can influence shelf-life of meat: temperature, atmospheric oxygen, water activity $\left(a_{w}\right)$, light, endogenous enzymes and microbiological development. All of these factors cause changes in color, odor, flavor and texture. Although the deterioration of meat can be due to processes such as proteolysis, lipolysis and oxidation, microbial growth is the most important factor (Nychas, Marshall, \& Sofos, 2007). Microbial loads from $10^{7} \mathrm{CFU} \mathrm{cm} \mathrm{cm}^{-2}$ are associated with the occurrence of off-odors. Those off-odors can become fruity when the microbial counts rise and become putrid, as a result of amino acid consumption, for microbial counts greater than $10^{9} \mathrm{CFU} \mathrm{cm}^{-2}$. When the glucose present in the aqueous phase is used, other substrates are sequentially consumed with the released of odors of ammonia and nitrogenous compounds, such as dimethyl- 1 sulfide (Ercolini, Russo, Torrieri, Masi, \& Villani, 2006). Aerobic bacteria and Gram negative facultative anaerobic are considered the group with the greatest spoilage potential. Many members of the Enterobacteriaceae family contribute to the meat spoilage. However, in refrigerated meat stored under aerobic conditions, Pseudomonas, Acinetobacter, Psychrobacter and Moraxella present high growth rates (Ercolini et al., 2006) and the genus Pseudomonas is generally dominant, actively contributing to the deterioration, due to their ability to degrade glucose and amino acids at reduced temperatures (Mohareb et al., 2015). Although Acinetobacter would compete with Pseudomonas for amino acids and lactic acid, those have little affinity for oxygen, which favors Pseudomonas (Ercolini et al., 2006). Even though the dominant spoilage microflora in the fresh meat is generally Gram negative, the initial population can include Gram positive genera such as Lactic Acid Bacteria (LAB) and Brochothrix thermosphacta (Mohareb et al., 2015). LAB plays an important role in the spoilage of refrigerated fresh meat and are important competitors of other groups of deteriorative microorganisms. Brochothrix thermosphacta is a microorganism that may develop under aerobic and anaerobic conditions, resulting in the release of off-odors (Ellis et al., 2002).

Recently it has been observed a growing interest in the search for natural products with antimicrobial and antioxidant properties in order to replace chemical and synthetic additives currently used in the food industry (Wang, Wu, Zu, \& Fu, 2008).

Since ancient times, spices and herbs are used not only for medicinal purposes but also to improve organoleptic characteristics of food (Calo, Crandall, O'Bryan, \& Ricke, 2015). EOs can be used as food preservatives to improve food hygiene, reducing the microbiota development and enhancing shelf-life of meat. They are aromatic oily liquids obtained from various organs of plants such as flowers, leaves, seeds, roots, fruits and others (Korifi, Le Dréau, Antinelli, Valls, \& Dupuy, 2013). They are secondary metabolites synthesized by herbs as a form of protection from bacteria, virus, fungi, insects, herbivores and the climate. On the other hand they can attract some insects to promote the dispersal of pollen and seeds (Burt, 2004).

The antibacterial, antiviral, anti-parasitic, anti-mycotic, antitoxicogenic activity and insecticidal properties of some EOs are well known, hence the interest in the study of its applicability in foodstuff preservation (Burt, 2004).

The quality, quantity and chemical composition of the EOs may vary according to the weather and composition of the soil, plant organ from it is extracted, age and stage of the growth cycle (Bakkali, Averbeck, Averbeck, \& Idaomar, 2008). Thus, in order to obtain EOs of constant composition, plants must be collected under the same conditions.

In vitro physical and chemical studies characterize most of the compounds present in EOs as antioxidants. Depending on the concentration, these can be cytotoxic but are generally nongenotoxic (Bakkali et al., 2008). The characteristics of the food matrix such as lipid composition, proteins, $\mathrm{a}_{\mathrm{w}}, \mathrm{pH}$ and enzymes can diminish or enhance the effectiveness of the EOs. According to Bajpai, Baek, and Kang (2012), low pH may increase the solubility and stability of the EO increasing the antimicrobial capacity.

According to Fisher and Phillips (2008), the compounds present in the EO penetrate the protein structure of the cell wall causing protein denaturation and destruction of the cell membrane. Thus, the operation of the cellular components, including the core, are reduced by the presence of compounds in the EOs due to changes in cell membrane permeability (Fisher \& Phillips, 2008).

Some studies suggest that generally Gram positive bacteria are more sensitive to compounds of the EOs than Gram negative bacteria; this is thought to be related to the Gram negative impermeable outer membrane (Fisher \& Phillips, 2008). However, according to Smith-Palmer, Stewart, and Fyfe (2001), over time the EOs ultimately have the same effect on both types.

Rosemary (Rosmarinus officinalis L.) is a shrub that grows in all Mediterranean countries. Of the different species ( $R$. officinalis, $R$. eriocalyx, $R$. lavandulaceus and $R$. laxiflorus), only $R$. officinalis grows naturally in the Mediterranean (Angioni et al., 2004; Tassou \& Nychas, 1995). Besides being used for centuries as a food flavoring, it is also very important in traditional medicine and it is used to combat cramping and relieve the symptoms of diseases of the nervous system (Miresmailli, Bradbury, \& Isman, 2006; Wang et al., 2008). $R$. officinalis L. is one of the spices with anti-inflammatory (Steiner et al., 2001) and high antioxidant properties (Bozin, Mimica-Dukic, Samojlik, \& Jovin, 2007), attributed to phenolic compounds such as carnosol, carnosic acid, rosmanol, rosmadial, epirosmanol, rosmadiferol and rosmarinic acid. These compounds promote the maintenance of the nervous tissues (Offord, Aescgbach, Loliger, \& Pfeifer, 1997). Carnosic acid has anticancer properties, inhibiting the proliferation of abnormal cells (Chan, Ho, \& Huang, 1995; Kosaka \& Yokoi, 2003). It is effective in controlling various pathogenic and deteriorative microorganisms (Chan et al., 1995).

Laurel (Laurus Nobilis L.) is an evergreen shrub or tree native of the southern Mediterranean region (Sellami et al., 2011). Its dried leaves and EO are used in the food industry as a spicy for flavoring and food preservative and are used in folk medicine (Ali-Shtayeh et al.,2000Ali-Shtayeh, Yaniv, \& Mahajna, 2000) (Kilic, Hafizoglu, Kollmannsberger, \& Nitz, 2004; Ramos et al., 2012). According to Sellami et al. (2011), 1,8-cineole is the major laurel EO component with percentages ranging between 31.4 and 56\%. Other compounds were present in appreciable amounts include linalool, transsabinene hydrate, $\alpha$-terpinyl-acetate, methyl eugenol, sabinene and eugenol. Benzene compounds present in percentages ranging between 1 and 12\%, are responsible for the spicy aroma of the leaves and are extremely important factors determining its sensory quality.

The purpose of this work was to assess the effect of EOs of laurel (Laurus Nobilis L.) and rosemary (Rosmarinus officinallis L.) naturally occurring in Trás-os-Montes e Alto Douro, Portugal, on the spoilage of fresh Maronesa beef burgers stored at 2 and $8{ }^{\circ} \mathrm{C}$ under different packaging conditions.

\section{Material and methods}

\subsection{Extraction of essential oils}

For the extraction of EOs, leaves of laurel (Laurus Nobilis L.) and rosemary (Rosmarinus officinallis L.) were obtained from wild regions in northern Portugal. The material was weighed and dried in an oven at approximately $40^{\circ} \mathrm{C}$ until no weight change was found and sealed under vacuum until used. In order to obtain the EOs, the material was submitted to hydro-distillation using a Clevenger-type apparatus for $3 \mathrm{~h}$. In this method, the dried sample is ground and put in a volumetric flask with distilled water $(1: 10)$, placed in a heating 
mantle and under the Clevenger-type apparatus which is connected to a condenser. As water boils the formed vapor carries the volatile compounds retained in the sample, which condenses in contact with the condenser falling in the Clevenger column while the EO stays at the surface due to its lower density. With a Pasteur pipette the EO was collected and stored in small tubes, at $4{ }^{\circ} \mathrm{C}$ and protected from light. The yield was expressed in $\% \mathrm{v} / \mathrm{w}$.

\subsection{Volatile composition of EOs by gas chromatography-mass spectrometry and gas chromatography-thermal conductivity detection}

The analysis by gas chromatography (GC) was performed using a Thermo Scientific ${ }^{\mathrm{TM}}$ TRACE ${ }^{\mathrm{TM}} 1300$ gas chromatograph coupled to an ISQ ${ }^{\mathrm{TM}}$ Series Single Quadrupole MS Systems mass spectrometer (MS).

The analytes separation was performed with a Thermo Scientific TG-5MS column $(60 \mathrm{~m} \times 0.25 \mathrm{~mm} \times 0.25 \mu \mathrm{m})$. The oven temperature program was as follows: initial temperature of $60^{\circ} \mathrm{C}$ held for $2 \mathrm{~min}$, increasing to $280^{\circ} \mathrm{C}$ at a rate of $10.00^{\circ} \mathrm{C} / \mathrm{min}$ and held for $5 \mathrm{~min}$. Samples and standards were prepared prior to analysis using $n$-hexane (Merck) at concentrations of 1.0 and $0.2 \%$ $(\mathrm{v} / \mathrm{v})$, respectively, and a volume of $1.0 \mu \mathrm{L}$ was injected using an auto-sampler. The injector was set to split mode (1:5), operating at $250{ }^{\circ} \mathrm{C}$ and $165 \mathrm{kPa}$. The mass spectrometer's transfer line and the ion source temperature was set to 280 and 250 , respectively, with the last operating under electron impact mode $(70 \mathrm{eV}$, mass scan range 30-400 amu).

Analysis of the same samples was also carried out using a Shimadzu ${ }^{\text {TM }}$ GC-2010 Plus (Shimadzu Corporation, Japan). Separation of analytes was performed with a Zebron ZB-5 column $(30 \mathrm{~m} \times 0.25 \mathrm{~mm} \times 0.25 \mu \mathrm{m})$ using a similar oven temperature program and injection/injector parameters except for carrier gas flow which was set to $82.5 \mathrm{kPa}$. The detector temperature and current was programmed to $300^{\circ} \mathrm{C}$ and $75 \mathrm{~mA}$, respectively, with a make-up flow of $5.0 \mathrm{~mL} / \mathrm{min}$.

All analytical separations were made using helium with 99.999\% purity as carrier gas.

Identification of analytes was performed by comparison of the Kovats and Linear Retention Indices, using NIST/EPA/NIH Mass Spectral Library (2011) and other libraries, and by comparison of authentic standards.

\subsection{Sampling}

Fresh beef (semitendinosus and semimembranosus) of DOPMaronesa breed (males; $n=4$ ) were obtained from local market and transported to the laboratory. After cut and minced, $20 \mathrm{~g}$ samples were individually packed in duplicate in two different conditions: aerobiosis (A) and vacuum (V) with and without EO (control). Samples were stored at 2 and $8^{\circ} \mathrm{C}$ and analyzed at $1,2,3$, $5,7,10,14$ and 21 days for $A$ and 1, 7, 14, 21, 28 and 35 days for $V$ for microbiological, $\mathrm{pH}$ and color ( $\left.\mathrm{L}^{*} \mathrm{a}^{*} \mathrm{~b}^{*}\right)$ in one hour after open package. The microorganisms analyzed were Lactic acid bacteria (LAB), Enterobacteriaceae, Pseudomonas spp., Fungi, Total Mesophilic (TM) and Psychrotrophic (TP).

\subsection{Microbiological analysis}

The collection and weighing of the samples was accomplished by removing, aseptically, $10 \mathrm{~g}$ of each hamburger which was diluted in $90 \mathrm{~mL}$ of tryptone salt solution ( $0.3 \%$ tryptone and $\mathrm{NaCl}$ at $0.85 \%$, sterilized at $121^{\circ} \mathrm{C}$ for $15 \mathrm{~min}$ ) and homogenized in "stomacher" for $30 \mathrm{~s}$. Successive decimal dilutions were performed in test tubes containing $9 \mathrm{~mL}$ sterile tryptone salt. Afterwards, they were sown by incorporation or at the surface depending on the microorganism and the culture medium. Colony counting results were expressed as $\log \mathrm{CFU} / \mathrm{g}$.

For TM (ISO4833, 1991) and TP (PortugueseStandard2307, 1987), spreading was made by incorporation of $1 \mathrm{~mL}$ of the original suspension and the respective dilutions on PCA (Plate Count Agar), spread plates were incubated at $30^{\circ} \mathrm{C}$ for $72 \mathrm{~h}$ for the $\mathrm{TM}$ and $7{ }^{\circ} \mathrm{C}$ for 10 days for TP.

For Enterobacterieceae (ISO5552, 1997) spreading was done by addition of $1 \mathrm{~mL}$ of the original suspension and the respective dilutions on VRBG selective medium (Violet Red Bile Glucose Agar) (Scharlau 01-295-500) with double layer. The plates were placed at $37^{\circ} \mathrm{C}$ and after $24 \mathrm{~h}$, typical colony counting was performed (color pink to red, with or without precipitation halos or mucoid colonies undefined color). According to (ISO5552, 1997), 5 colonies were peaked and transferred to nutrient agar and placed at $30^{\circ} \mathrm{C}$ for $24 \mathrm{~h}$ to make the oxidase test (Biochemical confirmation) and glucose fermentation capacity among Glucose Agar (Harrigan \& McCance, 1979). It was considered true when the result was positive to oxidase and glucose as well.

Regarding Pseudomonas spp. (FrenchStandardV04-504 (AFNOR), 1998) spreading was done by incorporation of $1 \mathrm{~mL}$ of the original suspension and the respective dilutions through selective culture CFC (Cetrimide, Fucidin, Cephaloridine) with Pseudomonas Agar base (OXOID CM0559) and CFC selective supplement (OXOID SR0103). The spread plates were incubated at $25^{\circ} \mathrm{C}$ for $72 \mathrm{~h}$. After colony counting, 5 were transplanted to nutrient agar and incubated at $30^{\circ} \mathrm{C}$ for $24 \mathrm{~h}$, then subjected to biochemical characterization of the test oxidase (positive) and by growth aerobically in the middle of KLIGLER (KLIGLER Iron Agar) (OXOID CM0033).

LAB (FrenchStandardV04-503(AFNOR), 1988) spreading was done by addition of $1 \mathrm{~mL}$ of the original suspension and the respective dilution in double layer selective medium MRS (Man Rogosa Sharpe Agar) (Oxoid CM0361). The seeded plates were incubated at $30^{\circ} \mathrm{C}$ for $72 \mathrm{~h}$.

For fungi (ISO13681,1995) spreading was done on the surface of $0.1 \mathrm{~mL}$ of the original suspension and the respective dilutions through selective culture GCA (Glucose Chloramphenicol Agar) (VWR 84604.0500).

\section{5. $\mathrm{pH}$ and color}

The $\mathrm{pH}$ value was obtained by the arithmetic average of three measurements made with a $\mathrm{pH} 330 i$ WTW $\mathrm{pH}$ meter placed directly in a body sample hamburger.

The color measurement was carried out on a hamburger samples with about $1-1.5 \mathrm{~cm}$ thickness. Three measurements were performed on each sample $60 \mathrm{~min}$ after opening the individual package. The color measurement was performed using a reflectometer Minolta Chromo Meter CR-310 (Minolta, Japan) through the CIELAB color system of L*a*b* (D65 illuminant).

\section{Experimental results and discussion}

\subsection{Essential oils yield}

The yield of essential oils (EOs) from dried leaves of Rosmarinus officinalis L. and Laurus Nobilis L. were, respectively, 0.61 and $0.58 \%$ (v/w). As referred by Serrano, Palma, Tinoco, Venâncio, and Martins (2002) and Angioni et al. (2004), the essential oil yield presents variations with the place where the leaves were collected, with the season and the vegetative state. Nevertheless, in this study, the yield attained for rosemary was similar to the average value of $\approx 0.57 \%$ reported by Serrano et al. (2002) for Rosmarinus officinalis L. collected in different Alentejo's zones (Portugal). Regarding Laurus nobilis L. essential oil, the yield attained in this study is 
greater (0.58\%) than the one obtained at Sellami et al. (2011), study in the same conditions $(\approx 0.35 \%)$ which can be explained by the geographical difference where the leaves were collected.

\subsection{Volatile composition of EOs}

GC-MS analysis of rosemary and laurel EOs resulted in the detection of $95.75 \%$ and $89.42 \%$ of its compounds, respectively.

Table 1

Gas chromatography-mass spectrometry analysis (GC-MS) of rosemary and laurel essential oils.

\begin{tabular}{|c|c|c|c|c|}
\hline \multirow{2}{*}{$\begin{array}{l}\text { Kovats } \\
\text { index }\end{array}$} & \multirow{2}{*}{$\begin{array}{l}\text { Retention } \\
\text { time }\end{array}$} & \multirow[t]{2}{*}{ Identified Compound } & \multicolumn{2}{|l|}{$\%$ peak } \\
\hline & & & $\begin{array}{l}\text { Rosmarinus officinalis } \\
\text { L. }\end{array}$ & Laurus Nobilis L. \\
\hline 600 & 6.97 & cn-Hexane & 0.24 & \\
\hline 851 & 7.39 & ${ }^{\mathrm{a} 1}$ 2-Hexenal, (E)- & 0.73 & \\
\hline 858 & 7.40 & b13-Hexen-1-ol & & 0.38 \\
\hline 900 & 8.24 & ${ }^{\mathrm{c}}$ Nonane & 0.33 & 0.35 \\
\hline 933 & 8.89 & ${ }^{\mathrm{a} 2} \alpha$-Thujene & & 0.21 \\
\hline 940 & 9.08 & ${ }^{\mathrm{a} 2} \alpha$-Pinene, (D)- & 7.44 & 2.12 \\
\hline 952 & 9.42 & ${ }^{\mathrm{a} 2}$ Camphene & 3.29 & \\
\hline 957 & 9.49 & ${ }^{\mathrm{a} 2} 2,4(10)$-Thujadiene & 0.68 & \\
\hline 977 & 9.83 & ${ }^{\mathrm{a} 2}$ Sabinene & & 4.10 \\
\hline 979 & 9.96 & ${ }^{\mathrm{a} 2}(-)-\beta$-Pinene & 2.95 & 2.91 \\
\hline 981 & 9.99 & ${ }^{\mathrm{a} 2} \beta$-Myrcene & 3.35 & 2.87 \\
\hline 990 & 10.03 & ${ }^{\mathrm{a} 2}( \pm)-\beta$-Pinene & 3.3 & 1.12 \\
\hline 1007 & 10.42 & ${ }^{\mathrm{a} 2} \beta$-Thujene & 0.2 & \\
\hline 1012 & 10.55 & ${ }^{2} 23$-Carene & 0.69 & 0.84 \\
\hline 1019 & 10.65 & ${ }^{\mathrm{a} 2} \alpha$-Terpinene & 0.49 & \\
\hline 1025 & 10.8 & ${ }^{\mathrm{a} 2} \mathrm{p}-$-Cymene & 0.33 & \\
\hline 1030 & 10.92 & ${ }^{\mathrm{a} 2} \mathrm{~d}$-Limonene & 3.12 & \\
\hline 1033 & 10.99 & ${ }^{\mathrm{a} 1} 1,8$ cineole (Eucalyptol) & 15.86 & 18.47 \\
\hline 1058 & 11.42 & ${ }^{\mathrm{a} 2} \gamma$-Terpinene & 0.87 & 0.65 \\
\hline 1163 & 11.61 & ${ }^{a}$ trans- $\beta$-Terpineol (p-Menth-1-en-8-ol) & & 0.57 \\
\hline 1073 & 11.85 & ${ }^{\mathrm{d}}$ Diallyl disulphide (4,5-dithia-1,7-octadiene) & 0.27 & 0.81 \\
\hline 1076 & 11.92 & ${ }^{\mathrm{a} 1}$ cis- $\beta$-Terpineol (p-Menth-8-en-1-ol) & & 0.25 \\
\hline 1084 & 12.00 & ${ }^{\mathrm{a} 2} \alpha$-Terpinolene & 0.8 & \\
\hline 1098 & 12.09 & ${ }^{\mathrm{a}} \beta$-Linalool & 3.7 & 19.97 \\
\hline 1108 & 12.30 & a12-Pinen-7-one (Crisantenone) & 0.36 & \\
\hline 1145 & 13.20 & ${ }^{\mathrm{a}}{ }_{(+)-2-B o r n a n o n e}($ Camphor) & 9.32 & \\
\hline 1169 & 13.56 & a1 endo-Borneol & 8.79 & \\
\hline 1179 & 13.66 & ${ }^{\mathrm{a} 1}$ Terpinen-4-ol & 4.26 & 3.01 \\
\hline 1191 & 13.86 & ${ }^{\mathrm{a} 1} \alpha$-Terpineol & 3.64 & 4.52 \\
\hline 1200 & 14.00 & ${ }^{\mathrm{a} 1}$ Myrtenol & 2.24 & \\
\hline 1218 & 14.33 & ${ }^{\mathrm{a} 1} \mathrm{~L}-$ Verbenone & 9.36 & \\
\hline 1228 & 14.54 & ${ }^{\mathrm{a} 1} \mathrm{Nerol}$ & 0.62 & 1.02 \\
\hline 1241 & 14.72 & b2 Linalyl o-aminobenzoate & & 1.57 \\
\hline 1248 & 14.85 & 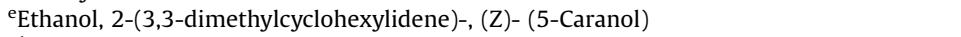 & 0.53 & \\
\hline 1272 & 15.25 & ${ }^{\mathrm{a} 1} \mathrm{p}$-Mentha-1,8-dien-3-one & 0.39 & \\
\hline 1290 & 15.35 & ${ }^{\mathrm{a} 1}$ Thymol & & 0,31 \\
\hline 1291 & 15.45 & ${ }^{\mathrm{a} 1} \mathrm{~L}$ - $\alpha$-bornyl acetate & 3.87 & \\
\hline 1297 & 15.63 & ${ }^{\mathrm{a}}(-)$-trans-Pinocarvyl acetate & 0.27 & \\
\hline 1325 & 16.02 & ${ }^{\mathrm{a} 1}$ Myrtenyl acetate & & 1.75 \\
\hline 1343 & 16.37 & ${ }^{\mathrm{a} 1} \alpha$-Terpineol acetate & & 11.74 \\
\hline 1345 & 16.40 & ${ }^{\mathrm{a} 1}$ Nerol acetate & & 0.52 \\
\hline 1351 & 16.54 & ${ }^{\mathrm{e}}$ Eugenol & & 1.62 \\
\hline 1383 & 16.69 & ${ }^{\mathrm{a} 1}$ Geranyl acetate & & 0.81 \\
\hline 1327 & 16.98 & e3,5-Heptadienal, 2-ethylidene-6-methyl- & 0.27 & \\
\hline 1401 & 17.09 & ${ }^{\mathrm{e}}$ Methyleugenol & & 2.25 \\
\hline 1427 & 17.72 & ${ }^{\mathrm{b} 2}$ Caryophyllene & 2.44 & \\
\hline 1476 & 18.69 & ${ }^{\mathrm{b} 2} \beta$-Selinene & & 0.71 \\
\hline 1556 & 19.19 & eElemicin & & 0.31 \\
\hline 1601 & 19.95 & b1 (-)-Spathulenol & & 1.17 \\
\hline 1609 & 20.07 & ${ }^{\mathrm{b} 1}$ Caryophyllene oxide & 0.75 & 0.50 \\
\hline 1621 & 20.19 & ${ }^{\mathrm{b} 1}$ Viridiflorol & & 0.31 \\
\hline 1640 & 20.34 & ${ }^{b 1}$ Ledol & & 0.28 \\
\hline 1642 & 20.69 & ${ }^{\mathrm{b} 1} \tau$-Muurolol & & 0.26 \\
\hline 1652 & 20.87 & ${ }^{\mathrm{b} 1} \alpha$-Cadinol & & 0.28 \\
\hline \multirow[t]{11}{*}{1654} & 20.93 & $\begin{array}{l}{ }^{\mathrm{b} 1} \beta \text {-Eudesmol; 2-Naphthalenemethanol, decahydro- } \alpha, \alpha, 4 \mathrm{a} \text {-trimethyl-8-methylene-, [2R- } \\
(2 \alpha, 4 \mathrm{a} \alpha, 8 \mathrm{a} \beta)]-\end{array}$ & & 0.55 \\
\hline & & Total & 95.75 & 89.42 \\
\hline & & ${ }^{\mathrm{a}}$ Monoterpenes & 90.92 & 77.82 \\
\hline & & ${ }^{\mathrm{a} 1}$ Oxygenated monoterpenes & 63.41 & 62.94 \\
\hline & & ${ }^{\mathrm{a} 2}$ Monoterpene hydrocarbons & 27.51 & 14.82 \\
\hline & & ${ }^{\mathrm{b}}$ Sesquiterpenes & 3.19 & 6.01 \\
\hline & & ${ }^{\mathrm{b} 1}$ Oxygenated sesquiterpenes & 0.75 & 3.73 \\
\hline & & ${ }^{\mathrm{b}}$ Sesquiterpene hydrocarbons & 2.44 & 2.28 \\
\hline & & ${ }^{\mathrm{c}}$ Aliphatic compounds & 0.57 & 0.35 \\
\hline & & ${ }^{\mathrm{d}}$ Non isoprenoids compounds & 0.27 & 0.81 \\
\hline & & ePhenylpropanoids & 0.8 & 4.43 \\
\hline
\end{tabular}


These are shown in Table 1 with its percentage, retention time and Kovats index. It is notorious that the identified compounds belong majorly to the monoterpenes class, particularly oxygenated monoterpenes representing $63.41 \%$ and $62.94 \%$ of the total for rosemary EO and laurel EO, respectively.

For rosemary EO the main constituents detected were 1.8 cineole (15.86\%), L-verbenene (9.36\%), endo-Borneol (8.79\%), camphor $(9.32 \%)$ and $\alpha$-Pinene $(7.44 \%)$. According to (Flamini, Cioni, Morelli, Macchia, \& Ceccarini, 2002) rosemary EOs can be divided in two chemical groups: one which is mainly composed by $\alpha$-pinene $(\approx 20.6 \%)$ followed by 1.8 cineole $(\approx 6.6 \%)$ and another whose predominant compound is 1,8 cineole $(\approx 40.2 \%)$ followed by $\alpha$-pinene $(\approx 13.2 \%)$. Taking this into consideration, it can be said that the rosemary EO obtained in this study is closer to the second group, being however the concentrations lower than the referenced ( 1.8 cineole $-15.86 \%$; $\alpha$-pinene $-7.44 \%$ ). Other common compounds on rosemary EO are D-limonene, $\beta$-pinene and $\mathrm{L}-\alpha$ -bornyl acetate (Nowak, Kalemba, Krala, Piotrowska, \& Czyzowska, 2012), these compounds are also found in our sample in amounts of $3.12 \%, 6.25 \%$ and $3.87 \%$, respectively.

According to Santoyo et al. (2005) and Jiang et al. (2011), $\alpha$-pinene, 1.8 cineole, L-verbenene, camphor and endo-Borneol are the main compounds that exhibit antimicrobial effect in rosemary
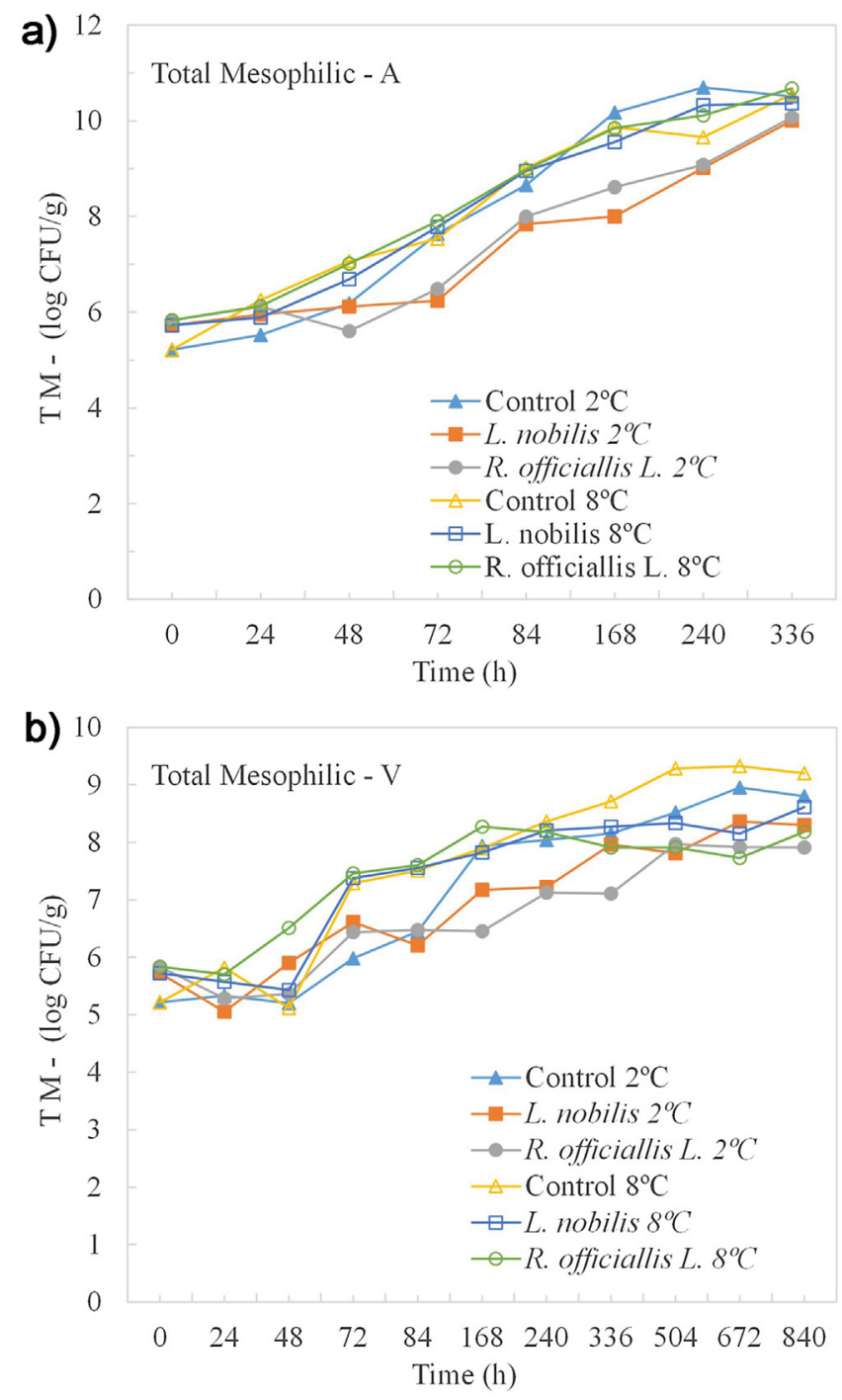

Fig. 1. Time evolution of total mesophilic (TM) for samples stored at 2 and $8{ }^{\circ} \mathrm{C}$ in a) aerobiosis (A) and in b) vacuum (V).
EO. In this study the extracted OE presents relevant concentrations of these compounds $(7.44 ; 15.86 ; 9.36 ; 9.32$ and $8.79 \%$, respectively). In Ojeda-Sana, van Baren, Elechosa, Juárez, and Moreno (2013)'s study myrcene (3,35\% in this study) was shown to have high antioxidant activity.

Regarding laurel EO, 35 compounds were determined, representing $89.42 \%$ of the total content. The 6 main compounds were $\beta$-linalool (19.97\%), 1,8 cineole (18.47\%), $\alpha$-Terpineol acetate (11.74\%), sabinene (4.10\%), $\alpha$-terpineol (4.52\%) and terpinen-4-ol (3.10\%), representing $61.90 \%$ of the total determined compounds. Some authors (Cherrat et al., 2014; Hadjibagher Kandi \& Sefidkon, 2011; Sellami et al., 2011; Silveira et al., 2014) have reported higher levels of sabinene and 1,8 cineole whereas for linalool and terpinen-4-ol the contents obtained by the authors mentioned above were lower.

In the study performed by Silveira et al. (2014), similar results for laurel EO compounds were achieved; this essential oil showed not only relevant antimicrobial and antioxidant effect but was also very effective maintaining meat's (sausages) $\mathrm{pH}$ levels.

Nevertheless, it is important to keep in mind that according to various authors not only the main compounds that exhibit bactericidal and antioxidant effect but the interaction between these and the compounds in lower concentration that also play an
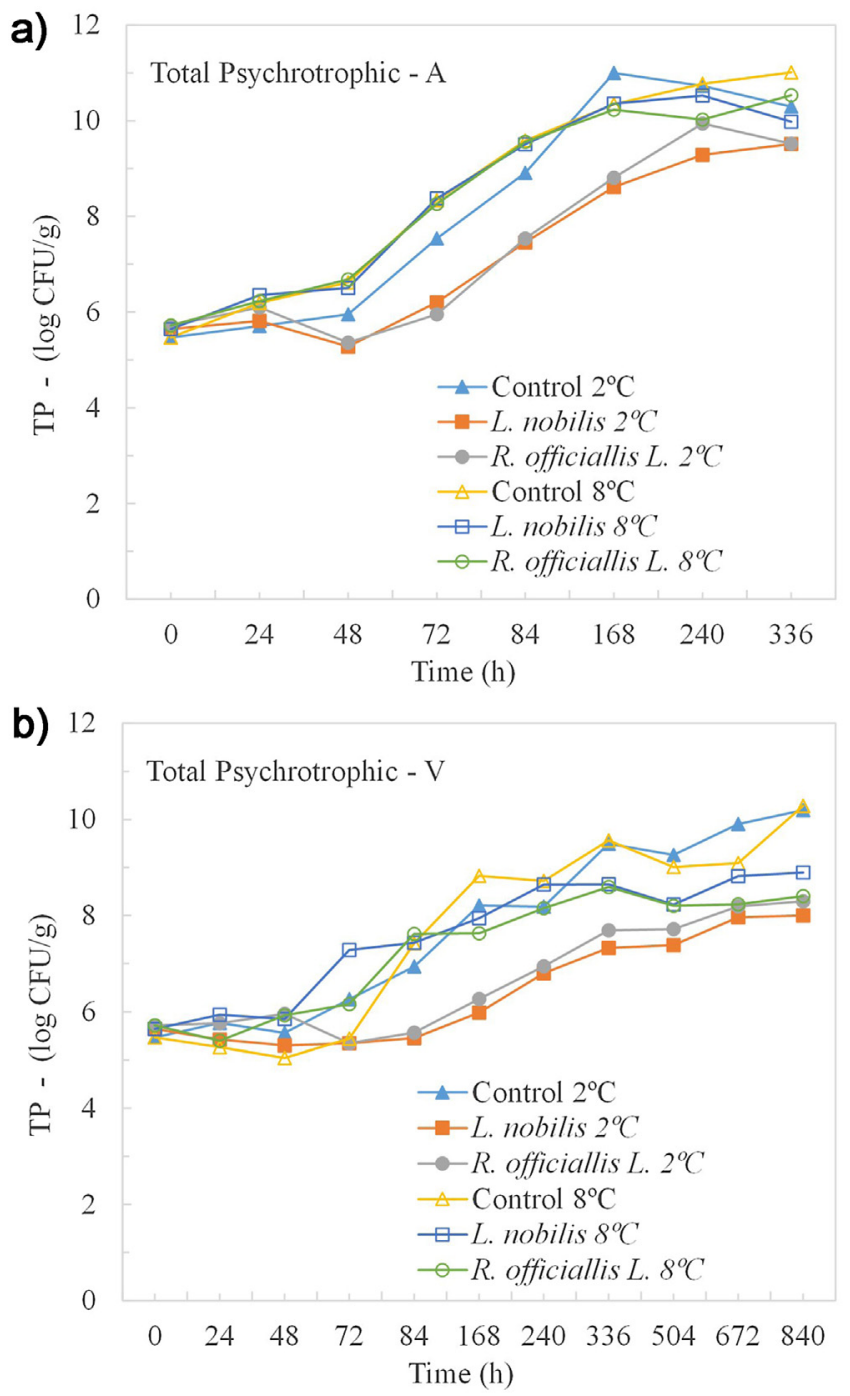

Fig. 2. Time evolution of total psychrotrophic (TP) for samples stored at 2 and $8{ }^{\circ} \mathrm{C}$ in a) aerobiosis (A) and in b) vacuum (V). 
important role (Burt, 2004; Hyldgaard, Mygind, \& Meyer, 2012; Ojeda-Sana et al., 2013).

\subsection{Microbiological parameters}

Figs. 1-5 illustrate the time evolution of TM, TP, LAB, Pseudomonas spp. and Enterobacteriaceae for samples stored at 2 and $8{ }^{\circ} \mathrm{C}$ in $\mathrm{A}$ and $\mathrm{V}$ packages, respectively. All samples in $\mathrm{V}$ presented less counts compared with those packed in A. In terms of temperature all samples stored at $2{ }^{\circ} \mathrm{C}$ present less counts than samples stored at $8^{\circ} \mathrm{C}$. Therefore, as expected, the better combination for beef storage revels to be the $\mathrm{V}$ packaging under $2{ }^{\circ} \mathrm{C}$.

From Fig. 1a) it can be seen that for storage in A package under $2{ }^{\circ} \mathrm{C}$ above $48 \mathrm{~h}$ EOs reduced TM counts by almost $1 \log \mathrm{CFU} / \mathrm{g}$ while under $8^{\circ} \mathrm{C}$ the EOs show no relevant effect.

Fig. 1b) shows, for samples stored in $\mathrm{V}$ under $2{ }^{\circ} \mathrm{C}$, a decrease of TM counts for samples with EOs being the most effective rosemary EO with counts being in average $1.5 \mathrm{log}$ UFC/g lower than the control samples. Below $84 \mathrm{~h}$ of storage both EOs presented no visible effect. Furthermore, after $240 \mathrm{~h}$ of storage, rosemary EO presents inhibitory effect on TM.
Regarding TP, from Fig. 2a) (A) under $2{ }^{\circ} \mathrm{C}$, it can be noticed that after $48 \mathrm{~h}$ of storage both laurel and rosemary EO present positive effect reducing counts. At $8^{\circ} \mathrm{C}$, EOs effect can only be seen after $168 \mathrm{~h}$ being rosemary EO the most effective.

For samples stored in $\mathrm{V}$ under $2{ }^{\circ} \mathrm{C}$ - as it can be observed in Fig. 2b) - both EO have similar effect. After $72 \mathrm{~h}$ there is a notorious increase of TP counts of control samples as compared to both EOs samples. It must be noticed a difference of more than $1 \log \mathrm{UFC} / \mathrm{g}$ between control and EOs samples. For samples stored under $8^{\circ} \mathrm{C}$, TP counts are not affected by the presence of EOs although there is a significant decrease of TP counts from $168 \mathrm{~h}$ and forward.

Concerning LAB, as it is shown on Fig. 3a) for samples stored in A under $2{ }^{\circ} \mathrm{C}$, after $72 \mathrm{~h}$ both EOs have positive effect on inhibiting growth. Namely, the control counts are more than $1.5 \log \mathrm{UFC} / \mathrm{g}$ higher than EOs counts. For samples stored under $8^{\circ} \mathrm{C}$ after $84 \mathrm{~h}$ EOs show very similar effect being more efficient on reducing counts when compared to control samples.

As illustrated in Fig. $3 \mathrm{~b}$ ) for $\mathrm{V}$ packed samples under both 2 and $8^{\circ} \mathrm{C}$ there is no evident effect showed by laurel nor rosemary EOs.

Fig. 4a) represents the time evolution of Pseudomonas spp. for samples stored at 2 and $8{ }^{\circ} \mathrm{C}$ in $\mathrm{A}$, it may be seen for both temperatures that the two EOs were successfully on inhibiting its
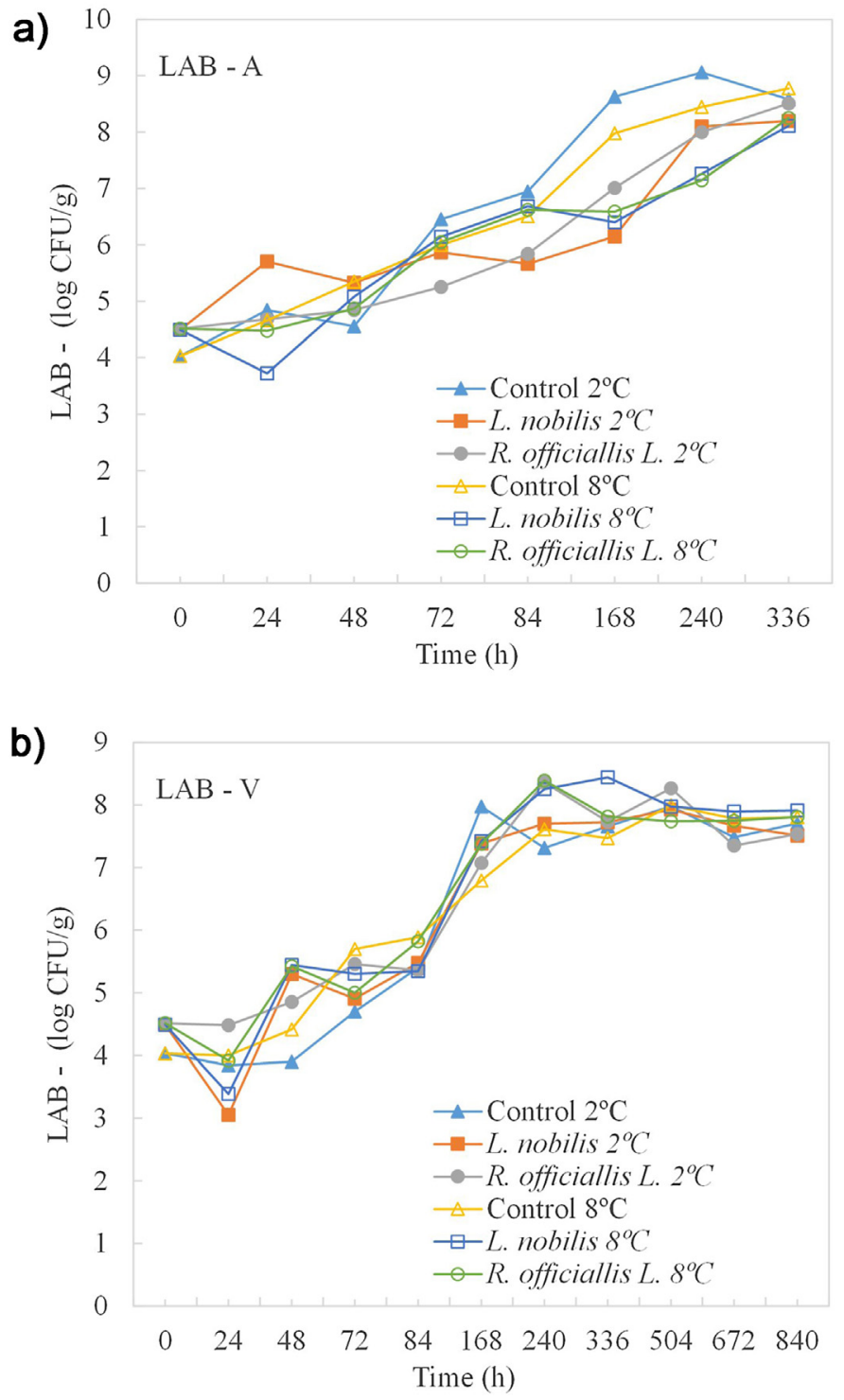

Fig. 3. Time evolution of lactic acid bacteria (LAB) for samples stored at 2 and $8^{\circ} \mathrm{C}$ in a) aerobiosis (A) and in b) vacuum (V). 
growth being laurel EO the most effective for samples under $2^{\circ} \mathrm{C}$ and rosemary EO better under $8^{\circ} \mathrm{C}$. It is notorious that samples with EOs present a constant evolution at both temperatures in opposition to control samples which present a growth increase. Also, the final counts are much approximated to the initial counts on samples with EOs whereas control samples' final counts are about $4 \log \mathrm{CFU} / \mathrm{g}$ higher than initial counts.

For V - as it may be seen in Fig. 4b) - the two EOs are effective reducing Pseudomonas spp. counts at both temperatures being their effect very similar. In this packaging condition there is not a detachment as high as observed in A, but samples with EOs still present less counts than control samples. For all samples under $2{ }^{\circ} \mathrm{C}$ final counts are lower than initial counts, samples under $8^{\circ} \mathrm{C}$ have a minor increase in counts with exception of control samples that presents a difference of 2 more $\log$ CFU/g compared with initial counts. It is important to refer that control samples stored in $V$ package present lower variation of counts compared with control samples stored in A package. This can be explained by the atmosphere much more favorable to the development of specific spoilage microorganisms, such as Pseudomonas spp. in air than under vacuum system (Labadie, 1999; Nychas, Skandamis, Tassou, \& Koutsoumanis, 2008). According to Varnam and Sutherland (1995), Pseudomonas spp. can multiply in atmospheres with low
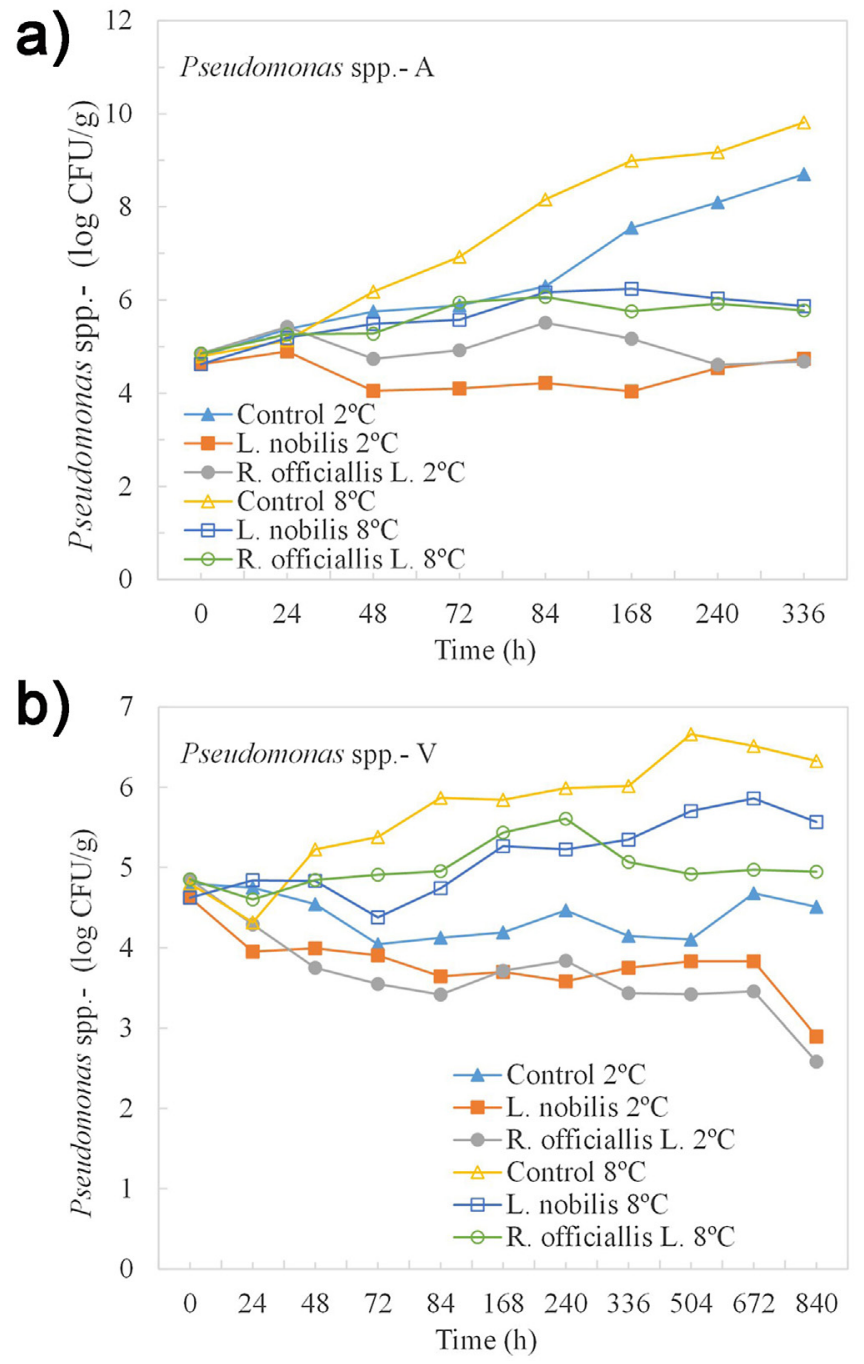

Fig. 4. Time evolution of Pseudomonas spp. for samples stored at 2 and $8{ }^{\circ} \mathrm{C}$ in a) aerobiosis (A) and in b) vacuum (V). concentration of $\mathrm{O}_{2}$, hence its behavior in vacuum whose amount of residual $\mathrm{O}_{2}$ may be sufficient to support its development.

In Fig. 5a) it can be noticed that for samples stored under both temperature EOs presented very similar effect maintaining Enterobacteriaceae counts below control samples counts. Nevertheless, under $2{ }^{\circ} \mathrm{C}$ laurel EO was the one with lesser counts in general. However, Enterobacteriaceae are not considered the main competitors in air and under vacuum, comparatively for example to Pseudomonas spp. in air and LAB in vacuum package (Doulgeraki, Ercolini, Villani, \& Nychas, 2012; Labadie, 1999).

For $V$ as it is shown in Fig. 5b) the effect of EOs is more evident and although for $2{ }^{\circ} \mathrm{C}$ the two EOs have similar effect, under $8^{\circ} \mathrm{C}$ laurel EO demonstrates the best effect obtaining lower counts compared with both rosemary samples and control samples with difference of almost $1 \log$ CFU/g and $2 \log$ CFU/g respectively.

In both packaging conditions, Enterobacteriaceae final counts are much higher than initial counts which can be explained by the fact that this microorganism can multiply in both aerobiosis and vacuum package (Brightwell, Clemens, Urlich, \& Boerema, 2007).

\section{4. $\mathrm{pH}$ analysis}

Table 2 presents the initial and final $\mathrm{pH}$ values for samples stored at 2 and $8{ }^{\circ} \mathrm{C}$ under $\mathrm{A}$ and $\mathrm{V}$ atmospheres. The initial $\mathrm{pH}$ of samples
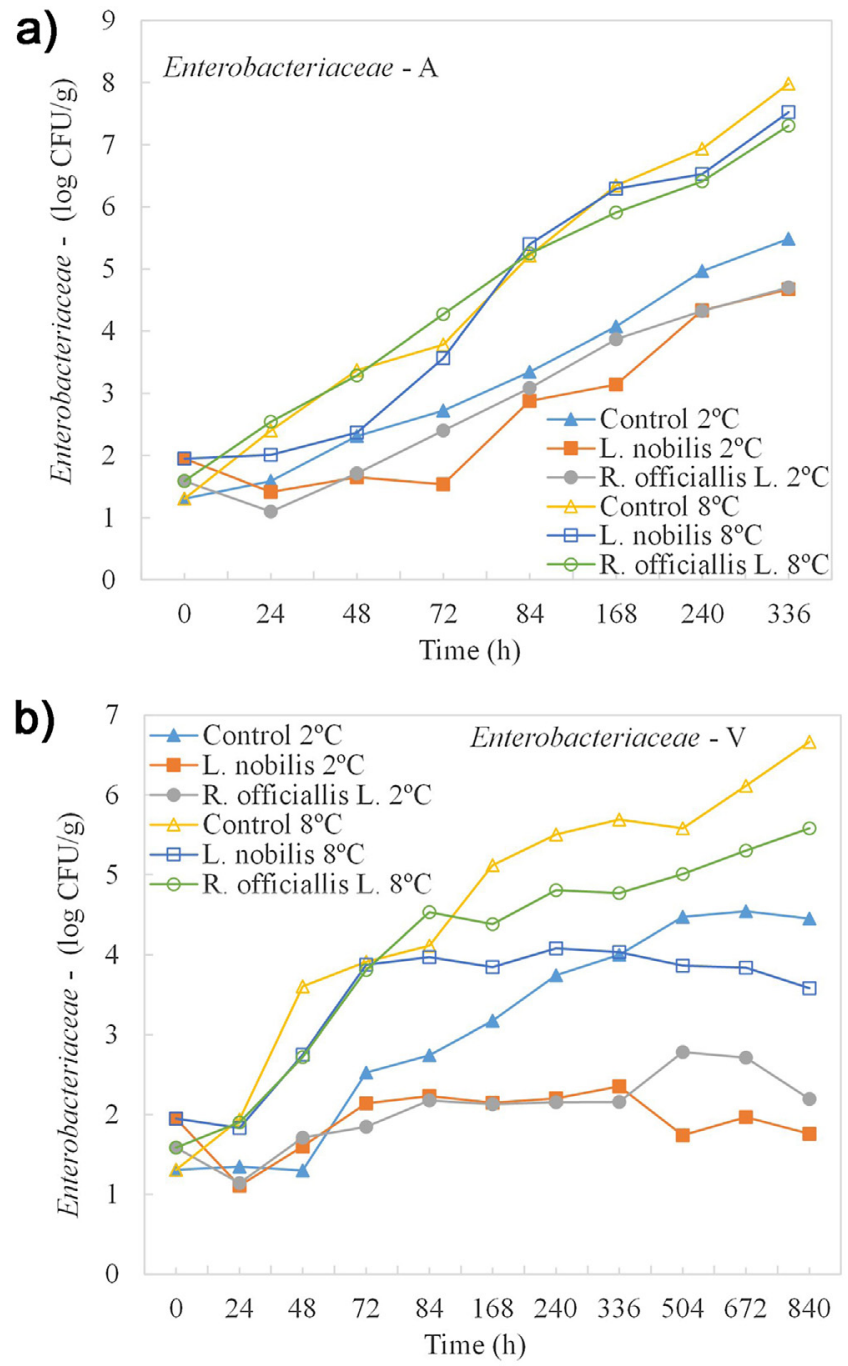

Fig. 5. Time evolution of Enterobactereaceae for samples stored at 2 and $8{ }^{\circ} \mathrm{C}$ in a) aerobiosis (A) and in b) vacuum (V). 
Table 2

Initial and final $\mathrm{pH}$ values for samples stored at 2 and $8{ }^{\circ} \mathrm{C}$ under different packaging conditions, aerobiosis (A) and vacuum (V).

\begin{tabular}{lllll}
\hline Samples & Time & $\mathrm{pH}$ & & \\
\cline { 3 - 5 } & & $\mathrm{T}\left({ }^{\circ} \mathrm{C}\right)$ & $\mathrm{A}$ & $\mathrm{V}$ \\
\hline Control & $\mathrm{t}=0$ & & 5.7 & 5.7 \\
& Final & 2 & 7.3 & 5.3 \\
Laurus nobilis L. & & 8 & 7.6 & 5.4 \\
& $\mathrm{t}=0$ & & 5.7 & 5.7 \\
Rosmarinus officiallis L. & Final & 2 & 6.6 & 5.5 \\
& & 8 & 7.6 & 5.5 \\
& $\mathrm{t}=0$ & & 5.7 & 5.7 \\
& Final & 2 & 7.2 & 5.5 \\
& & 8 & 7.7 & 5.6 \\
\hline
\end{tabular}

was 5.7, a value that falls in the expected range of 5.6-5.9 for beef after slaughter. No significant differences were observed between the two EOs samples but a reduction of final $\mathrm{pH}$ value, with exception of Laurel at $2^{\circ} \mathrm{C}$, comparatively to control samples can be observed. There were no significant differences between samples stored at 2 and $8{ }^{\circ} \mathrm{C}$, however it can be seen that in $\mathrm{A}$ the $\mathrm{pH}$ values for the two temperatures are clearly different while in $\mathrm{V}$ they are very similar. Samples stored under $\mathrm{V}$ package presented lower $\mathrm{pH}$ values and had
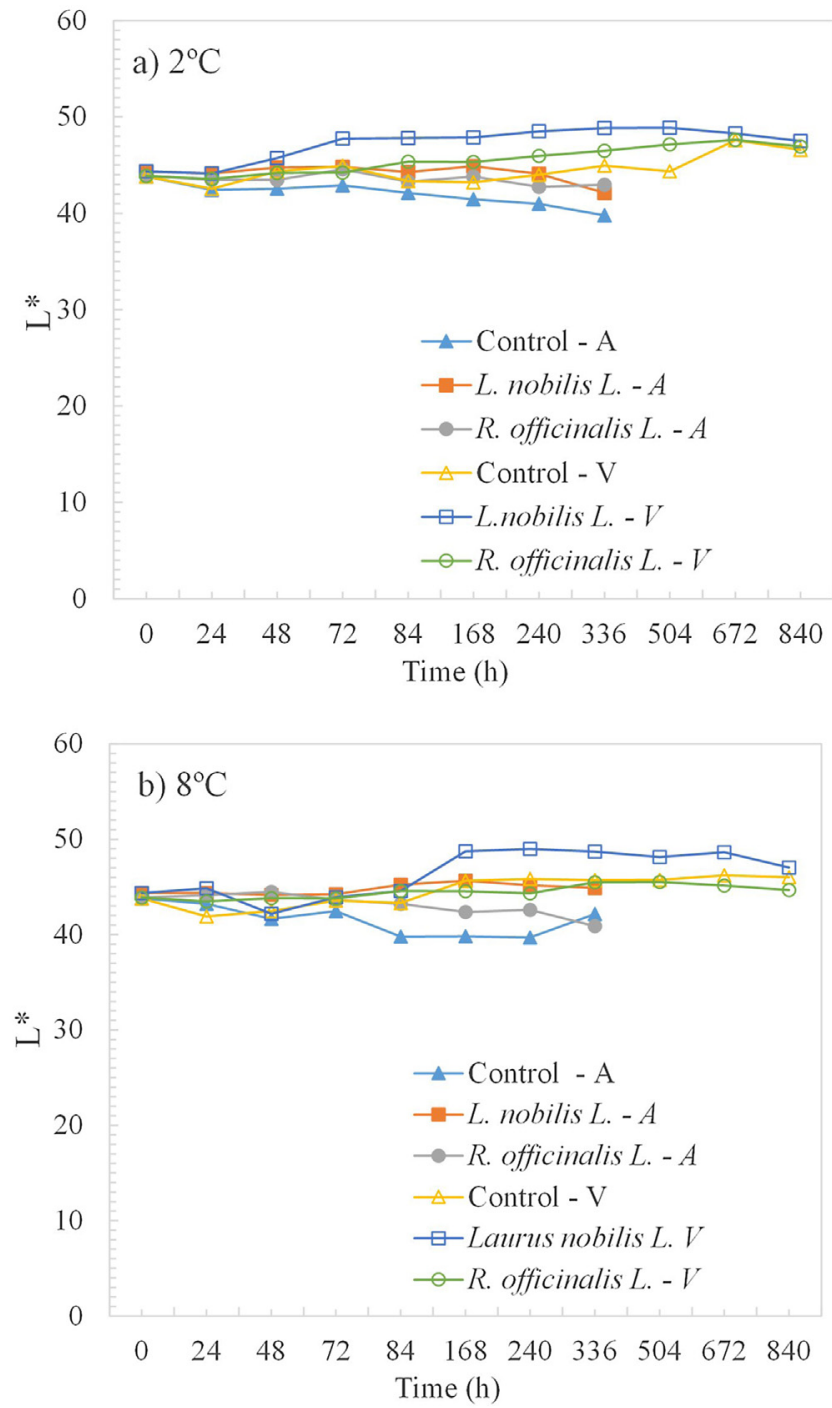

Fig. 6. Evolution of $\mathrm{L}^{*}$ coordinate over time for storage in different types of packaging aerobiosis (A) and vacuum (V)) at a) $2{ }^{\circ} \mathrm{C}$ and b) $8{ }^{\circ} \mathrm{C}$. the best result in minimizing $\mathrm{pH}$ variations (min. 5.3; max. 5.6) compared to A packaged samples (min. 6.6; max.7.7). These highest $\mathrm{pH}$ values observed in A packed samples can be due to the production of volatiles amines by specific microorganisms of spoilage, such as Pseudomonas spp. which found in this atmosphere the adequate conditions for their growth (Labadie, 1999). The advantage of $\mathrm{V}$ packaging is that the growth of these aerobic microorganisms is inhibited, however the deterioration eventually starts as a result of the multiplication of organisms able to tolerate anaerobic conditions (Balamurugan, Ahmed, \& Chambers, 2013).

\subsection{Color analysis}

The $\mathrm{L}^{*}$ parameter corresponds to the brightness of the meat. The analysis of Fig. 5 shows that the package influences the $\mathrm{L}^{*}$ parameter. In the case of $\mathrm{A}$ package there was a steady decrease of the $L^{*}$ coordinate which may be due to the transformation of oxymyoglobin (red) in metamyoglobin (brown) through oxidation and a rapid reduction can be observed at $8^{\circ} \mathrm{C}$. On $\mathrm{V}$ package it can be seen in all samples a steady increase of brightness over time with values higher than in A samples. These values were expected since in this condition occurs the formation of oxymyoglobin (red) from deoxymyoglobin (purplish) after open
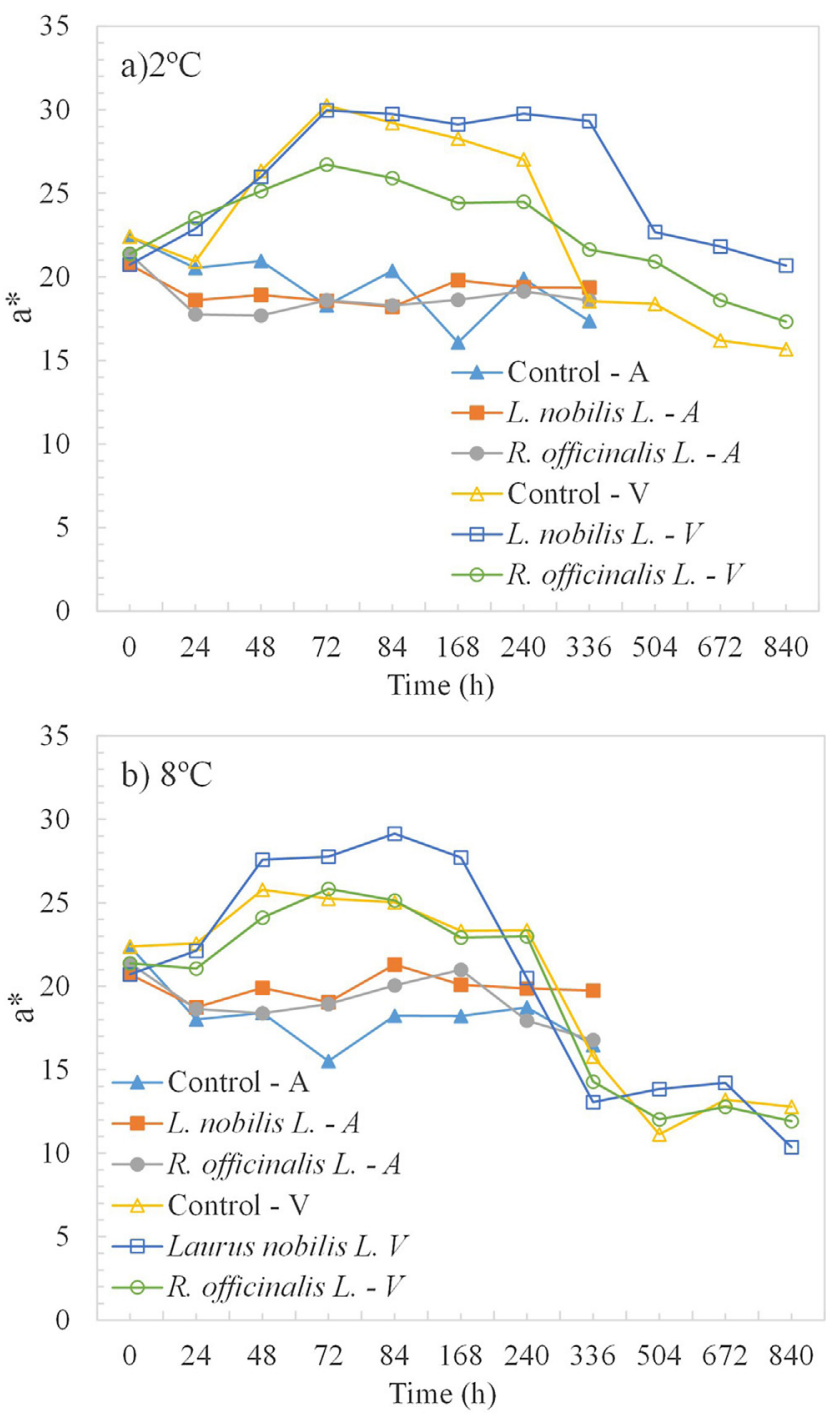

Fig. 7. Evolution of $a^{*}$ coordinate over time for storage in different types of packaging aerobiosis (A) and vacuum (V)) at a) $2{ }^{\circ} \mathrm{C}$ and b) $8{ }^{\circ} \mathrm{C}$. 

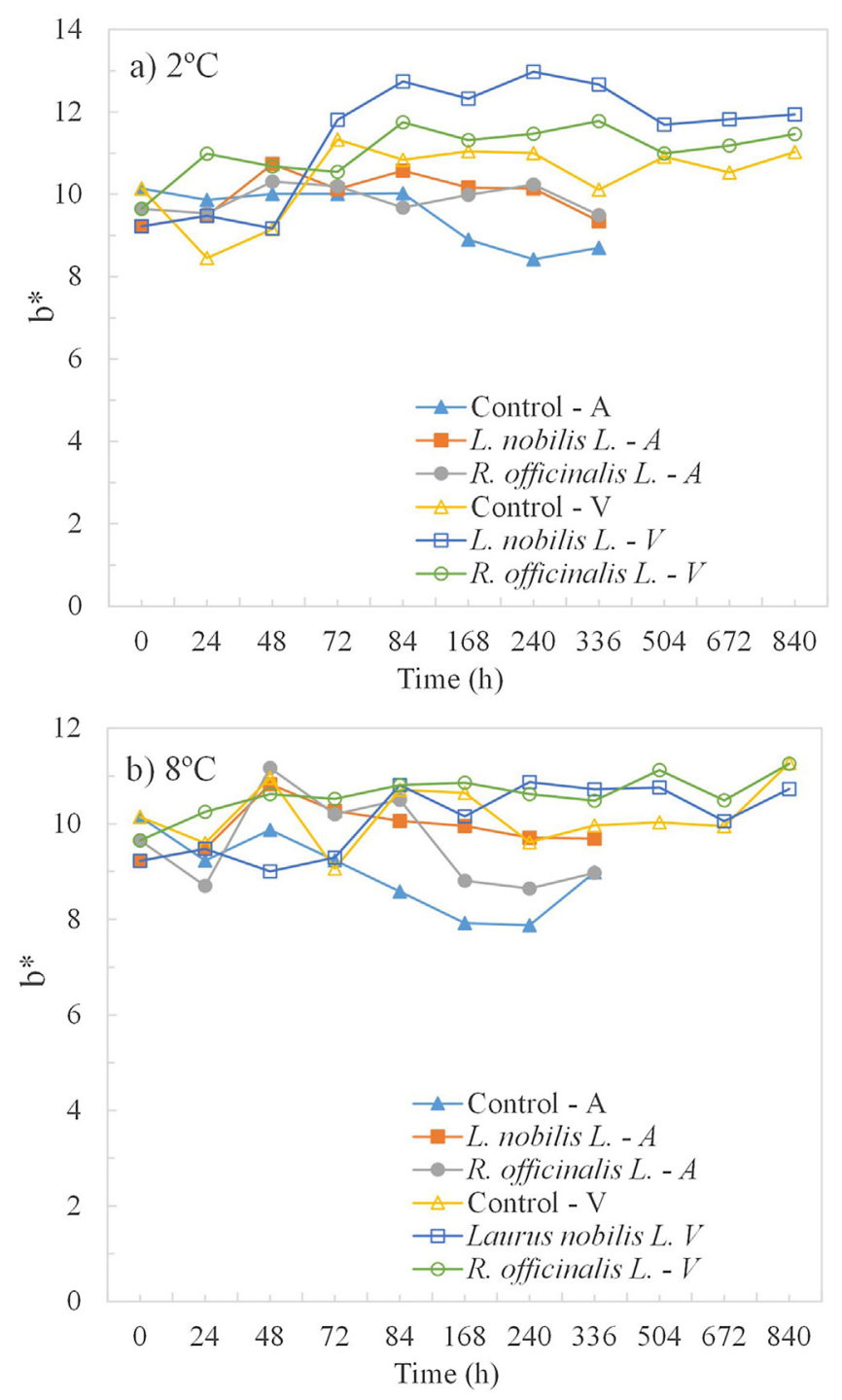

Fig. 8. Evolution of $b^{*}$ coordinate over time for storage in different types of packaging (A) and vacuum (V)) at a) $2{ }^{\circ} \mathrm{C}$ and b) $8{ }^{\circ} \mathrm{C}$.

package meat samples and exposition to the air (Pennacchia, Ercolini, \& Villani, 2011). In addition, there are not great differences between 2 and $8^{\circ} \mathrm{C}$ (Fig. 6).

Fig. 7 displays the measured values of the $a^{*}$ coordinate. The higher the $a^{*}$ coordinate the greater will be the red color. In this case the type of packaging also had effect on meat color. In both packages the $a^{*}$ value decreased over time. This reduction will occur in meat on any packaging after some time. The $\mathrm{V}$ package was found to be the one with greater preservation of red color until about $240 \mathrm{~h}$ and concerning to the temperature factor, $2{ }^{\circ} \mathrm{C}$ showed better results compared to $8^{\circ} \mathrm{C}$ samples, even though both had very similar values. For this packaging there was a considerably higher rise in the first few days which can be explained by the contact of the meat sample with oxygen when removed from the package (Strydom \& Hope-Jones, 2014). For A package there was a relatively constant loss of red color and the variation was not so obvious at an early stage, while in the last days of storage the values decreased considerably which indicates the metamyoglobin formation on the sample surface.

Fig. 8 displays the measured values of the $b^{*}$ coordinate. It can be seen that it had approximately the same value for the two temperatures. Moreover, it can be observed a slight rise at the beginning of the storage followed by a decrease (3-7 days at $2{ }^{\circ} \mathrm{C}$ and
5-10 days at $8^{\circ} \mathrm{C}$ ) and then this coordinate seem to stabilize. There was a slight decrease of $b^{*}$ values on the package under A conditions and a slight increase for the packing under vacuum, which means that the packaging method that best retains the color is the $V$ package because the higher the $b^{*}$ value the lesser is the loss of red color.

In general, EOs presented a positive effect on the color of the meat. Laurel EO presented better effect on $\mathrm{L}^{*}$ and $\mathrm{a}^{*}$ values, yielding a better red color preservation. Both EO allowed higher $\mathrm{b}^{*}$ values.

\section{Conclusions}

This study allows to conclude that EOs from Laurus nobilis L. and Rosmarinus officinalis L. show some effect maintaining fresh beef color, which is an important index of quality for consumers and can be used as food preservatives to improve food hygiene reducing spoilage microbiota development and enhancing shelf-life of beef.

Concerning store conditions, as expected, vacuum package and $2{ }^{\circ} \mathrm{C}$ were the combination with better results.

The two EOs demonstrated some positive results not just by reducing spoilage microbiota counts. Laurus nobilis L. is better in maintaining the red meat color and controlling $\mathrm{pH}$ in samples at $2{ }^{\circ} \mathrm{C}$ which is an important factor for meat deterioration.

In a future investigation the influence of these two EOs combined should be studied.

\section{Acknowledgements}

This work is financed by National Funds through the FCT - Fundação para a Ciência e a Tecnologia (Portuguese Foundation for Science and Technology) within UID/CVT/00772/ 2013. This work is financed by the ERDF - European Regional Development Fund through the Operational Programme for Competitiveness and Internationalisation-COMPETE 2020 Programme, and by National Funds through the FCT - Fundação para a Ciência e a Tecnologia (Portuguese Foundtion for Science and Technology) within project «POCI-01-0145-FEDER-006961».

\section{References}

Ali-Shtayeh, M. S., Yaniv, Z., \& Mahajna, J. (2000). Ethnobotanical survey in the Palestinian area: a classification of the healing potential of medicinal plants. Journal of Ethnopharmacology, 73(1-2), 221-232. http://dx.doi.org/10.1016/ S0378-8741(00)00316-0.

Angioni, A., Barra, A., Cereti, E., Barile, D., Coïsson, J. D., Arlorio, M., \& Cabras, P. (2004). Chemical composition, plant genetic differences, antimicrobial and antifungal activity investigation of the essential oil of Rosmarinus officinalis L. Journal of Agricultural and Food Chemistry, 52(11), 3530-3535. http://dx.doi.org/ $10.1021 / \mathrm{jf0} 49913 \mathrm{t}$

Bajpai, V. K., Baek, K.-H., \& Kang, S. C. (2012). Control of Salmonella in foods by using essential oils: a review. Food Research International, 45(2), 722-734. http://dx. doi.org/10.1016/j.foodres.2011.04.052.

Bakkali, F., Averbeck, S., Averbeck, D., \& Idaomar, M. (2008). Biological effects of essential oils - a review. Food and Chemical Toxicology, 46(2), 446-475. http:// dx.doi.org/10.1016/j.fct.2007.09.106.

Balamurugan, S., Ahmed, R., \& Chambers, J. R. (2013). Survival of Arcobacter butzleri on vacuum packaged chill stored beef. Food Research International, 52(2), 503507. http://dx.doi.org/10.1016/j.foodres.2013.01.048.

Bozin, B., Mimica-Dukic, N., Samojlik, I., \& Jovin, E. (2007). Antimicrobial and antioxidant properties of rosemary and sage (Rosmarinus officinalis L. and Salvia officinalis L., lamiaceae) essential oils. Journal of Agricultural and Food Chemistry, 55(19), 7879-7885. http://dx.doi.org/10.1021/jf0715323.

Brightwell, G., Clemens, R., Urlich, S., \& Boerema, J. (2007). Possible involvement of psychrotolerant Enterobacteriaceae in blown pack spoilage of vacuumpackaged raw meats. International Journal of Food Microbiology, 119(3), 334-339. http://dx.doi.org/10.1016/j.ijfoodmicro.2007.08.024.

Burt, S. (2004). Essential oils: their antibacterial properties and potential applications in foods-a review. International Journal of Food Microbiology, 94(3), 223-253. http://dx.doi.org/10.1016/j.ijfoodmicro.2004.03.022.

Calo, J. R., Crandall, P. G., O’Bryan, C. A., \& Ricke, S. C. (2015). Essential oils as antimicrobials in food systems - a review. Food Control, 54, 111-119. http://dx. doi.org/10.1016/j.foodcont.2014.12.040

Chan, M. M.-Y., Ho, C.-T., \& Huang, H.-I. (1995). Effects of three dietary phytochemicals from tea, rosemary and turmeric on inflammation-induced 
nitrite production. Cancer Letters, 96(1), 23-29. http://dx.doi.org/10.1016/03043835(95)03913-H.

Cherrat, L., Espina, L., Bakkali, M., Garcia-Gonzalo, D., Pagan, R., \& Laglaoui, A. (2014). Chemical composition and antioxidant properties of Laurus nobilis L. and Myrtus communis L. essential oils from Morocco and evaluation of their antimicrobial activity acting alone or in combined processes for food preservation. Journal of the Science of Food and Agriculture, 94(6), 1197-1204. http://dx.doi.org/10.1002/ jsfa.6397.

Doulgeraki, A. I., Ercolini, D., Villani, F., \& Nychas, G.-J. E. (2012). Spoilage microbiota associated to the storage of raw meat in different conditions. International Journal of Food Microbiology, 157(2), 130-141. http://dx.doi.org/10.1016/j. ijfoodmicro.2012.05.020.

Ellis, D. I., Broadhurst, D., Kell, D. B., Rowland, J. J., \& Goodacre, R. (2002). Rapid and quantitative detection of the microbial spoilage of meat by fourier transform infrared spectroscopy and machine learning. Applied and Environmental Microbiology, 68(6), 2822-2828. http://dx.doi.org/10.1128/AEM.68.6. 28222828.2002.

Ercolini, D., Russo, F. Torrieri, E. Masi, P. \& Villani, F. (2006). Changes in the spoilage-Related microbiota of beef during refrigerated storage under different packaging conditions. Applied and Environmental Microbiology, 72(7), 46634671. http://dx.doi.org/10.1128/AEM.00468-06.

Fisher, K., \& Phillips, C. (2008). Potential antimicrobial uses of essential oils in food: is citrus the answer? Trends in Food Science \& Technology, 19(3), 156-164. http:// dx.doi.org/10.1016/j.tifs.2007.11.006.

Flamini, G., Cioni, P. L., Morelli, I., Macchia, M., \& Ceccarini, L. (2002). Main agronomic-productive characteristics of two ecotypes of Rosmarinus officinalis L. and chemical composition of their essential oils. Journal of Agricultural and Food Chemistry, 50(12), 3512-3517.

FrenchStandardV04-503(AFNOR). (1988). Viandes et produits à base des viande Dénombrement des Bactéries lactiques.

FrenchStandardV04-504(AFNOR). (1998). Microbiologie des aliments Dénombrement des Pseudomonas spp. dans les viandes et produits à base des viandes.

Hadjibagher Kandi, M. N., \& Sefidkon, F. (2011). The influense of drying methods on essential oil content and composition ofLaurus nobilisL. Journal of Essential Oil Bearing Plants, 14(3), 302-308. http://dx.doi.org/10.1080/ 0972060x.2011.10643938.

Harrigan, W. F., \& McCance, M. E. (1979). Métodos de laboratorio en microbiología de alimentos y productos lácteos. León (España): Academia.

Hyldgaard, M., Mygind, T., \& Meyer, R. L. (2012). Essential oils in food preservation: mode of action, synergies, and interactions with food matrix components. Frontiers in Microbiology, 3, 12.

ISO4833. (1991). Microbiology. General guidance for the enumeration of microrganisms - colony-count technique at $30^{\circ} \mathrm{C}$.

ISO5552. (1997). Meat and meat products. Detection and enumeration of Enterobacteriaceae without resuscitation- MPN technique and colony-count technique.

ISO13681. (1995). Meat and meat products. Enumeration of yeasts and moulds colony-count technique.

Jiang, Y., Wu, N., Fu, Y.-J., Wang, W., Luo, M., Zhao, C.-J., \& Liu, X.-L. (2011). Chemical composition and antimicrobial activity of the essential oil of Rosemary. Environmental Toxicology and Pharmacology, 32(1), 63-68.

Kilic, A., Hafizoglu, H., Kollmannsberger, H., \& Nitz, S. (2004). Volatile constituents and key odorants in leaves, buds, flowers, and fruits of Laurus nobilis L. Journal of Agricultural and Food Chemistry, 52(6), 1601-1606. http://dx.doi.org/10.1021/ jf0306237.

Kodogiannis, V. S., Pachidis, T., \& Kontogianni, E. (2014). An intelligent based decision support system for the detection of meat spoilage. Engineering Applications of Artificial Intelligence, 34, 23-36. http://dx.doi.org/10.1016/j. engappai.2014.05.001.

Korifi, R., Le Dréau, Y., Antinelli, J.-F., Valls, R., \& Dupuy, N. (2013). CIEL***b* color space predictive models for colorimetry devices - analysis of perfume quality. Talanta, 104, 58-66. http://dx.doi.org/10.1016/j.talanta.2012.11.026.

Kosaka, K., \& Yokoi, T. (2003). Carnosic acid, a component of rosemary (Rosmarinus officinalis L.), promotes synthesis of nerve growth factor in T98 G human glioblastoma cells. Biological and Pharmaceutical Bulletin, 26(11), 1620-1622. http://dx.doi.org/10.1248/bpb.26.1620.

Labadie, J. (1999). Consequences of packaging on bacterial growth. Meat is an ecological niche. Meat Science, 52(3), 299-305. http://dx.doi.org/10.1016/S03091740(99)00006-6.

Limbo, S., Torri, L., Sinelli, N., Franzetti, L., \& Casiraghi, E. (2010). Evaluation and predictive modeling of shelf life of minced beef stored in high-oxygen modified atmosphere packaging at different temperatures. Meat Science, 84(1), 129-136. http://dx.doi.org/10.1016/j.meatsci.2009.08.035.

Lund, M. N., Heinonen, M., Baron, C. P., \& Estévez, M. (2011). Protein oxidation in muscle foods: a review. Molecular Nutrition \&' Food Research, 55(1), 83-95. http://dx.doi.org/10.1002/mnfr.201000453.
Miresmailli, S., Bradbury, R., \& Isman, M. B. (2006). Comparative toxicity of Rosmarinus officinalis L. essential oil and blends of its major constituents against Tetranychus urticae Koch (Acari: tetranychidae) on two different host plants. Pest Management Science, 62(4), 366-371. http://dx.doi.org/10.1002/ps.1157.

Mohareb, F., Iriondo, M., Doulgeraki, A. I., Van Hoek, A., Aarts, H., Cauchi, M., et al. (2015). Identification of meat spoilage gene biomarkers in Pseudomonas putida using gene profiling. Food Control, 57, 152-160. http://dx.doi.org/10.1016/j. foodcont.2015.04.007.

Nowak, A., Kalemba, D., Krala, L., Piotrowska, M., \& Czyzowska, A. (2012). The effects of thyme (Thymus vulgaris) and rosemary (Rosmarinus officinalis) essential oils on Brochothrix thermosphacta and on the shelf life of beef packaged in highoxygen modified atmosphere. Food Microbiology, 32(1), 212-216.

Nychas, G.-J. E., Marshall, D. L., \& Sofos, J. N. (2007). Meat, poultry, and seafood, In L. R. B. Michael, \& P. Doyle (Eds.), Food microbiology: fundamentals and frontiers3rd ed. American Society of Microbiology Press.

Nychas, G.-J. E., Skandamis, P. N., Tassou, C. C., \& Koutsoumanis, K. P. (2008). Meat spoilage during distribution. Meat Science, 78(1-2), 77-89. http://dx.doi.org/ 10.1016/j.meatsci.2007.06.020.

Offord, E. A. G. F., Aescgbach, R., Loliger, J., \& Pfeifer, A. M. A. (1997). Antioxidant and biological properties of Rosemary components: implications for food and health. In F. Shahidi (Ed.), Natural antioxidants: chemistry, health effects, and applicationsUSA: AOCS Press pp. 88-86.

Ojeda-Sana, A. M., van Baren, C. M., Elechosa, M. A., Juárez, M. A., \& Moreno, S. (2013). New insights into antibacterial and antioxidant activities of rosemary essential oils and their main components. Food Control, 31(1), 189-195.

Pennacchia, C., Ercolini, D., \& Villani, F. (2011). Spoilage-related microbiota associated with chilled beef stored in air or vacuum pack. Food Microbiology, 28 (1), 84-93. http://dx.doi.org/10.1016/j.fm.2010.08.010.

PortugueseStandard2307. (1987). Food Microbiology General guidance for the enumeration of psychrotrophic microrganisms.

Ramos, C., Teixeira, B., Batista, I., Matos, O., Serrano, C., Neng, N., \& Marques, A. (2012). Antioxidant and antibacterial activity of essential oil and extracts of bay laurel Laurus nobilis Linnaeus (Lauraceae) from Portugal. Natural Product Research, 26(6), 518-529.

Sallam, K. I., \& Samejima, K. (2004). Microbiological and chemical quality of ground beef treated with sodium lactate and sodium chloride during refrigerated storage. LWT - Food Science and Technology, 37(8), 865-871. http://dx.doi.org/ 10.1016/j.lwt.2004.04.003.

Santoyo, S., Cavero, S., Jaime, L., Ibanez, E., Senorans, F., \& Reglero, G. (2005) Chemical composition and antimicrobial activity of Rosmarinus officinalis L essential oil obtained via supercritical fluid extraction. Journal of Food Protection $^{\mathbb{R}}$, 68(4), 790-795.

Sellami, I. H., Wannes, W. A., Bettaieb, I., Berrima, S., Chahed, T., Marzouk, B., et al. (2011). Qualitative and quantitative changes in the essential oil of Laurus nobilis L. leaves as affected by different drying methods. Food Chemistry, 126(2), 691697. http://dx.doi.org/10.1016/j.foodchem.2010.11.022.

Serrano, E., Palma, J., Tinoco, T., Venâncio, F., \& Martins, A. (2002). Evaluation of the essential oils of rosemary (Rosmarinus officinalis L.) from different zones of 'Alentejo' (Portugal). Journal of Essential Oil Research, 14(2), 87-92. http://dx.doi. org/10.1080/10412905.2002.9699779.

Silveira, S. M. D., Luciano, F. B., Fronza, N., Cunha, A. Jr., Scheuermann, G. N., \& Vieira, C. R. W. (2014). Chemical composition and antibacterial activity of Laurus nobilis essential oil towards foodborne pathogens and its application in fresh Tuscan sausage stored at $7^{\circ} \mathrm{C}$. LWT - Food Science and Technology, 59(1), 86-93. http:/ dx.doi.org/10.1016/j.lwt.2014.05.032.

Smith-Palmer, A., Stewart, J., \& Fyfe, L. (2001). The potential application of plant essential oils as natural food preservatives in soft cheese. Food Microbiology, 18 (4), 463-470. http://dx.doi.org/10.1006/fmic.2001.0415.

Steiner, M., Priel, I., Giat, J., Levy, J., Sharoni, Y., \& Danilenko, M. (2001). Carnosic acid inhibits proliferation and augments differentiation of human leukemic cells induced by 1,25-dihydroxyvitamin Dsub3 and retinoic acid. Nutrition and Cancer, 41(1-2), 135-144. http://dx.doi.org/10.1080/01635581.2001.9680624.

Strydom, P. E., \& Hope-Jones, M. (2014). Evaluation of three vacuum packaging methods for retail beef loin cuts. Meat Science, 98(4), 689-694. http://dx.doi. org/10.1016/j.meatsci.2014.05.030.

Tassou, C. C., \& Nychas, G. J. E. (1995). Antimicrobial activity of the essential oil of mastic gum (Pistacia lentiscus var. chia) on gram positive and gram negative bacteria in broth and in Model Food System. International Biodeterioration \& Biodegradation, 36(3-4), 411-420. http://dx.doi.org/10.1016/0964-8305(95) 00103-4.

Varnam, A. H., \& Sutherland, L. (1995). Meat and meat products - technology, chemistry and microbiology. London: Chapman and Hall.

Wang, W., Wu, N., Zu, Y. G., \& Fu, Y. J. (2008). Antioxidative activity of Rosmarinus officinalis L. essential oil compared to its main components. Food Chemistry, 108 (3), 1019-1022. http://dx.doi.org/10.1016/j.foodchem.2007.11.046. 